\title{
Profil Keterampilan Berpikir Kritis Mahasiswa Pendidikan Fisika Universitas Palangka Raya Dalam Proses Analisis Artikel Ilmiah
}

\author{
Fenno Farcis \\ Program Studi Pendidikan Fisika, Universitas Palangka Raya, Palangka Raya, 73111, Indonesia \\ fenno.farcis@fkip.upr.ac.id
}

\begin{abstract}
Abstrak
Penelitian ini merupakan penelitian eksploratif yang bertujuan untuk mengetahui profil keterampilan berpikir kritis mahasiswa Pendidikan Fisika Universitas Palangka Raya sebagai salah satu LPTK. Penelitian ini menggunakan pendekatan kuantitatif dan kualitatif. Metode pengumpulan data melalui observasi lapangan dari 40 mahasiswa sampel dengan menggunakan teknik cluster random sampling untuk melihat proses analisis artikel ilmiah dalam kegiatan pembelajaran dan menentukan kategori akademik mahasiswa. Data yang terkumpul berupa dokumen tertulis mahasiswa dan hasil wawancara dideskripsikan dan dianalisis setelah diadakan reduksi dan diperiksa keabsahannya dengan menggunakan metode triangulasi. Hasil penelitian menunjukkan bahwa profil keterampilan berpikir kritis mahasiswa pendidikan fisika Universitas Palangka raya dalam proses analisis artikel ilmiah adalah: 1) interpretasi 37,5\%,2) analisis $32,5 \%, 3$ ) evaluasi $27,5 \%, 4)$ inferensi $22,5 \%, 5$ ) eksplanasi $22,5 \%$, dan 6) regulasi diri $12,5 \%$ dengan rerata persentase $25,8 \%$. Perlu dilakukan upaya sistematis memperbaiki proses pembelajaran dalam upaya meningkatkan keterampilan berpikir kritis mahasiswa calon pendidik fisika.
\end{abstract}

Katakunci: analisis artikel ilmiah, keterampilan berpikir kritis

\section{Pendahuluan}

Rienties, Brouwer, \& Lygo-Baker (2013) dan Avalos (2011) berpendapat bahwa keberadaan pendidik yang berkualitas merupakan syarat mutlak hadirnya sistem dan praktik pendidikan yang berkualitas [1-2]. Pendidik berkualitas adalah individu yang terdidik dan terlatih dengan baik serta memiliki pengalaman yang kaya di bidangnya [3]. Jalal (2007) menyatakan bahwa peserta didik yang siap berkompetisi dalam dunia modern harus dididik oleh para pendidik yang memiliki kapasitas dan kompetensi yang memadai dengan kebutuhan masa depan [4]. Kebutuhan masa depan kita adalah sumber daya manusia (SDM) yang berkualitas. Kualitas SDM ditandai perkembangan cepat pola berpikir tingkat tinggi setiap individu untuk mempertahankan dirinya dan memenangkan persaingan. Pola berpikir tingkat tinggi yang dimaksudkan berupa kemampuan berpikir kreatif, kritis, pemecahan masalah, serta kemampuan mengambil keputusan [5]. Prasyarat untuk menguasai kemampuan berpikir tingkat tinggi tersebut adalah terkuasainya kemampuan generik sains, yaitu kemampuan berpikir ilmiah melalui kegiatan pengamatan, kesadaran tentang skala, bahasa simbolik, inferensi logika, hukum sebab akibat, logical frame, konsistensi logis, pemodelan dan abstraksi [6]. Brotosiswojo (2001) menyatakan bahwa kemampuan generik sains penting dalam membangun kepribadian, pola berpikir tingkat tinggi setiap insan Indonesia [7]. Hal tersebut dikarenakan kemampuan generik sains sebagai dasar dalam proses berpikir tingkat tinggi yang meliputi kemampuan berpikir kreatif, kritis, pengambilan keputusan dan pemecahan masalah kehidupan sehari-hari [8].

Fisika merupakan salah satu cabang IPA (sains) yang pada hakekatnya merupakan proses dan produk pengkajian gejala alam. Fisika adalah salah satu ilmu dasar (basic science) yang menjadi fondasi dalam pola berpikir individu untuk dikembangkan menjadi pendukung utama dalam pemecahan masalah, khususnya dengan penerapan ilmu praktis [9]. Kemampuan seseorang untuk dapat berhasil dalam kehidupannya antara lain ditentukan oleh keterampilan berpikirnya, terutama dalam upaya memecahkan masalah-masalah kehidupan yang dihadapinya [10]. Penguasaan materi fisika (sains) memerlukan keterampilan berpikir dasar [11] dan juga keterampilan berpikir kompleks (tinggi), termasuk berpikir kritis [9]. 
Facione (2015) berpendapat bahwa berpikir kritis pada dasarnya merupakan deskripsi yang rinci dari beberapa karakteristik yang meliputi proses interpretasi, analisis, evaluasi, inferensi, eksplanasi, dan regulasi diri. Terdapat beberapa hal yang menjadi ciri umum dari berpikir kritis, di antaranya mampu membuat dan mengevaluasi kesimpulan dengan menelaah permasalahan, bukti, dan solusi secara logis dan sistematis [12]. Mengacu pada beberapa hasil penelitian sebelumnya, melatihkan keterampilan berpikir kritis dalam pembelajaran dapat menjadi salah satu solusi untuk mengatasi rendahnya kemampuan hasil belajar dan rendahnya keterampilan berpikir kritis. Douglas \& Nancy (2007) menemukan bahwa yang mendasari perkembangan kemampuan peserta didik adalah kemampuan berpikir kritis sebagai keterampilan tertinggi dalam meningkatkan penguasaan ilmu pengetahuan [13]. Selain penguasaan konsepkonsep fisika, calon pendidik fisika sebagai peserta didik LPTK dituntut untuk memiliki kemampuan berpikir logis dan kritis, oleh karena itu model yang dikembangkan dalam pembelajaran hendaknya memfasilitasi aktivitas berpikir. Proses pengumpulan fakta dan informasi, berpikir menyimpulkan (deduksi dan induksi), dan melakukan analisis lanjut serta menyusun dan mengkomunikasikan hasil pengolahan data dalam eksperimen merupakan aktivitas berpikir kritis [14]. Berpikir kritis merupakan ranah berpikir tingkat tinggi, di mana pemikiran tingkat tinggi dapat dan seharusnya dilatihkan [12] secara persisten dan terus-menerus serta teliti [15], dan menurut Eggen \& Kauchak (2012) dapat dilatihkan dengan pola-pola pembelajaran sederhana [16]. dan dengan pemilihan strategi pembelajaran yang tepat. Berpikir kritis dapat dilatihkan dengan cara mempertanyakan apa yang dilihat dan didengar. Setelah itu dilanjutkan dengan bertanya mengapa dan bagaimana tentang hal tersebut. Informasi yang diperoleh harus diolah dengan baik dan cermat sebelum akhirnya disimpulkan. Ada beberapa hal yang menjadi ciri umum dari berpikir kritis di antaranya mampu membuat dan mengevaluasi kesimpulan dengan menelaah permasalahan, bukti, dan solusi secara logis dan sistematis [12].

Negara Indonesia mempersiapkan calon-calon pendidiknya pada suatu lembaga, yaitu LPTK (Lembaga Pendidik dan Tenaga Kependidikan) yang ada di setiap propinsi dan beberapa kabupaten di Indonesia. LPTK memiliki peran strategis dalam meningkatkan kualitas calon pendidik melalui peningkatan kemampuan berpikir mahasiswanya. Salah satu mata kuliah yang harus ditempuh oleh mahasiswa pendidikan fisika sebelum menyusun tugas akhir adalah mata kuliah metodologi penelitian. Mata kuliah metodologi penelitian adalah salah satu mata kuliah wajib pada jurusan pendidikan fisika. Mata kuliah ini bertujuan untuk membekali para mahasiswa tentang pengetahuan, pemahaman, dan penerapan berbagai metode penelitian dalam rangka penyusunan tugas akhir/skripsi. Pembelajaran metodologi penelitian membahas berbagai jenis penelitian fisika, langkah-langkah penelitian ilmiah mulai dari penentuan topik, identifikasi permasalahan, ulasan kepustakaan, penentuan fokus masalah, penentuan variabel, disain dan metode, teknik pengumpulan data, analisis, dan penarikan kesimpulan.

Proses pembelajaran metodologi penelitian bertujuan menghasilkan suatu karya ilmiah yang disusun secara mandiri oleh mahasiswa dengan menerapkan langkah-langkah metode ilmiah. Sebelum mampu menulis tentu saja mahasiswa dituntut untuk banyak membaca berbagai karya ilmiah. Kajian karya ilmiah yang telah dibaca oleh mahasiswa tentu saja dapat dijadikan pelatihan dalam proses berpikir kritis. Hasil penelitian Prahmana, Kusumah, \& Darhim (2016), Tatan (2012), dan Prahmana (2015) menemukan bahwa 1) terdapat hubungan yang positif antara keterampilan meneliti terhadap hasil pembuatan tugas akhir/skripsi, yang berarti semakin tinggi keterampilan mahasiswa dalam melakukan penelitian, maka hasil pembuatan skripsi mahasiswa juga semakin tinggi, 2) faktor yang menyebabkan mahasiswa menunda menyelesaian skripsi/tugas akhir adalah mahasiswa terbatas dalam pemahaman pembuatan skripsi dan pemahaman metode penelitian, dan 3) sintaks model pembelajaran berbasis riset memiliki peran yang besar dalam menumbuhkan keterampilan meneliti. [17-18]

Pemikiran berbagai ahli dan juga berbagai hasil penelitian yang telah diuraikan di atas merupakan dasar pemikiran perlunya dilakukan suatu kajian yang bertujuan untuk mengetahui 
keterampilan berpikir kritis mahasiswa Program Studi Pendidikan Fisika Universitas Palangka Raya.

\section{Bahan}

Bahan penelitian ini berupa instrumen Penilaian Keterampilan Berpikir Kritis (PKBK) dan Dokumen interview terhadap mahasiswa. Seluruh bahan penelitian dipergunakan dengan mengacu pada langkah-langkah yang termuat dalam metode penelitian.

\section{Metode}

Desain penelitian menggunakan metode deskriptif kualitatif dan kuantitatif yang diarahkan untuk menggali data dari kondisi di lapangan yang sebenarnya. Data yang dimaksud adalah keterampilan berpikir kritis mahasiswa dalam proses analisis artikel ilmiah. Penelitian deskriptif menjelaskan atau menggambarkan yang sedang terjadi [19], tidak dilakukan manipulasi atau perubahan variabel-variabel bebas sehingga menggambarkan kondisi yang sebenarnya. Penelitian dilaksanakan di Program Studi Pendidikan Fisika Universitas Palangka Raya. Sampel penelitian adalah mahasiswa tahun akademik 2014/2015 sampai dengan 2015/2016 yang telah pernah menempuh perkuliahan metodologi penelitian yang berjumlah 40 mahasiswa yang ditetapkan secara cluster random sampling. Instrumen yang digunakan adalah penilaian kemampuan berpikir kritis (PKBK). Analisis data dilakukan dengan analisis secara persentase kuantitatif dengan pembahasan secara kualitatif.

\section{Hasil dan Pembahasan}

Penilaian kemampuan berpikir kritis (PKBK) diberikan kepada mahasiswa sebagai evaluasi seluruh keterampilan. PKBK diberikan untuk mengevaluasi kemampuan berpikir kritis mahasiswa yang terdiri dari 6 (enam) indikator berpikir kritis, yaitu 1) interpretasi, 2) analisis, 3) evaluasi, 4) inferensi, 5) eksplanasi, dan 6) regulasi diri. PKBK diberikan kepada mahasiswa selaku subjek penelitian.

Instrumen penilaian keterampilan berpikir kritis mengacu pada tes yang telah dikembangkan sebelumnya, yaitu California Critical Thinking Skills Test (CCTST). Indikator keterampilan berpikir kritis yang digunakan dalam penelitian ini adalah indikator keterampilan berpikir kritis dari Facione. Setiap butir soal disesuaikan dengan indikator soal yang merujuk pada keterampilan berpikir kritis yang telah ditetapkan pada indikator. Setiap soal merupakan bagian terpisah dari soal yang berikutnya sehingga tidak bersifat sebagai prasyarat untuk penyelesaian soal-soal selanjutnya.

Penilaian keterampilan berpikir kritis yang dikembangkan berbentuk uraian obyektif yang memiliki jawaban dengan rumusan yang pasti, sehingga dapat dilakukan penskoran secara obyektif. Soal berjumlah 6 Soal yang dikerjakan oleh mahasiswa selama 120 menit. Skor keterampilan berpikir kritis (KBK) terkonversi ke dalam 5 (lima) kriteria, yaitu: $89 \%<\mathrm{x} \leq 100 \%$ (Sangat Tinggi); 78\% < $x \leq 89 \%$ (Tinggi); 64\% < $x \leq 78 \%$ (Sedang); 55\% $<\mathrm{x} \leq 64 \%$ (Rendah); $0 \%<\mathrm{x} \leq 55 \%$ (Sangat Rendah). Hasil PKBK disajikan pada Tabel 1.

Tabel 1 dan Gambar 1 menunjukkan hasil PKBK terdapat pada indikator interpretasi sebesar $37,5 \%$, indikator analisis $32,5 \%$, indikator evaluasi $27,5 \%$, indikator inferensi $22,5 \%$, eksplanasi 22,5\%, dan regulasi diri 12,5\%. Rata-rata ketercapaian keterampilan berpikir kritis mahasiwa Program Studi Pendidikan Fisika Universitas Palangka Raya kurang dari 55\% yaitu 25,8\%, hal ini menunjukkan bahwa keterampilan berpikir kritis mahasiswa berada pada kategori sangat rendah. 
Tabel 1. Keterampilan Berpikir Kritis Mahasiswa

\begin{tabular}{clc} 
No. & Indikator Keterampilan & $\begin{array}{c}\text { Persentase } \\
\text { Ketercapaian }(\boldsymbol{\%})\end{array}$ \\
\hline 1 & Interpretasi & 37,5 \\
2 & Analisis & 32,5 \\
3 & Evaluasi & 27,5 \\
4 & Inferensi & 22,5 \\
5 & Eksplanasi & 22,5 \\
6 & Regulasi Diri & 12,5 \\
\hline & Rata-rata & 25,8
\end{tabular}

Berdasarkan Tabel 1 dapat dibuat grafik keterampilan berpikir kritis sebagai berikut:

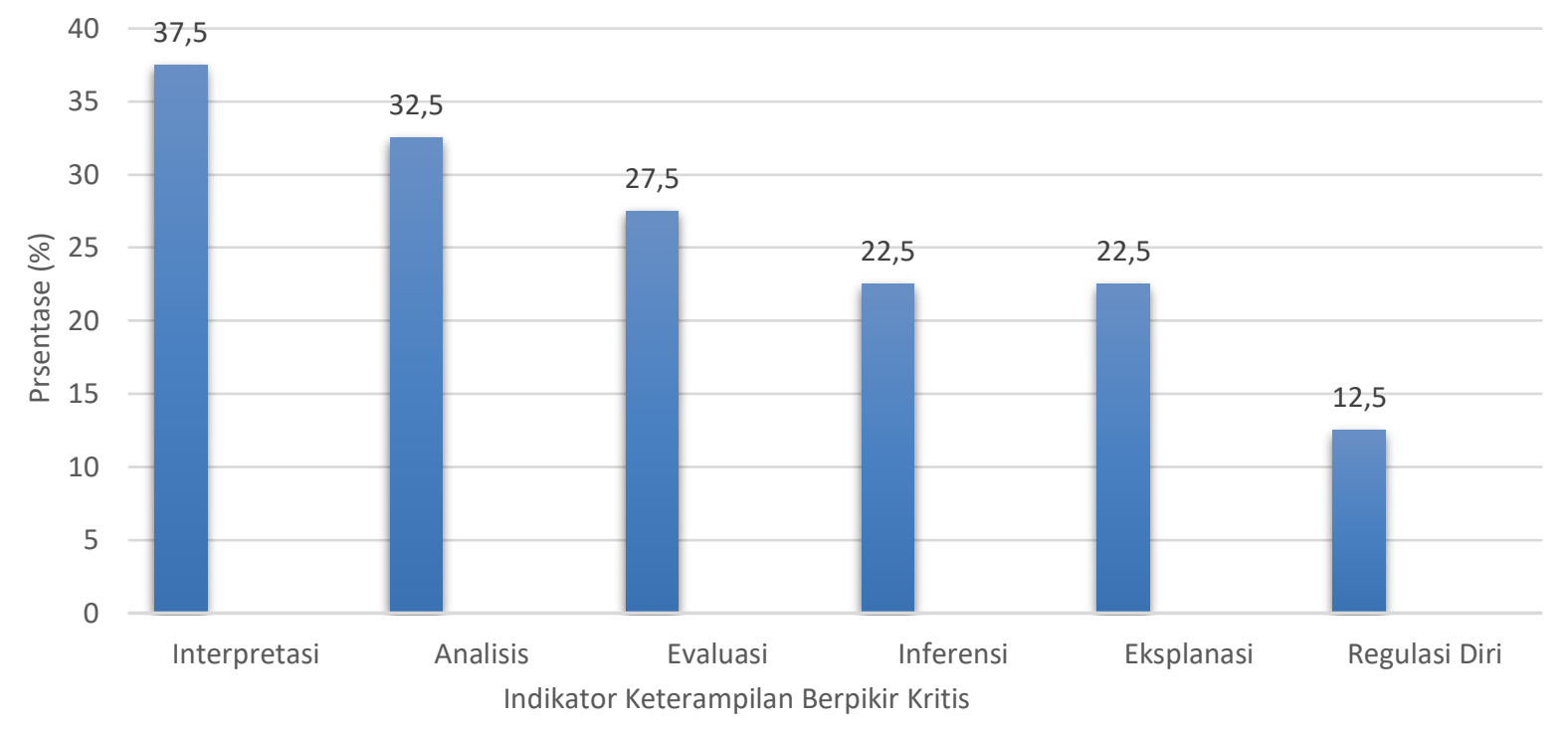

Gambar 1. Grafik Persentase Keterampilan Berpikir Kritis Mahasiswa

Rendahnya keterampilan berpikir kritis mahasiswa dimungkinkan karena beberapa hal, yang pertama, kurang terlatihnya keterampilan mahasiswa dalam mengidentifikasi dan mengklasifikasi konsep-konsep yang berada di dalam materi metodologi penelitian, kedua pemahaman dan latihan mahasiswa terhadap soal berpikir kritis masih sangat kurang. Selajutnya ketiga, mahasiswa belum terbiasa mengimplementasikan langkah-langkah metode ilmiah sebagai implikasi dari rendahnya frekuensi kegiatan di laboratorium. Keempat, mahasiswa kurang memahami latar belakang permasalah penelitian yang termuat di dalam artikel penelitian yang dianalisis, dan yang kelima, mahasiswa belum terbiasa mendefiniskan masalah dan merumuskan solusi alternatif.

Data penguat hasil penelitian yang digunakan adalah data hasil wawancara terhadap mahasiswa M18 dan M7 dengan kriteria keterampilan berpikir kritis tertinggi dan terendah. Hasil wawancara sebagai berikut.

Peneliti Apakah Anda mengetahui indikator keterampilan berpikir kritis?

M18 Tidak Bu, saya tidak tahu

M7 Tidak Bu, saya tidak tahu 


\begin{abstract}
Peneliti Apakah Anda mengetahui apa yang dimaksud dengan keterampilan berpikir kritis?

M18 Tidak Bu saya tidak tahu

M7 Tidak Bu, saya tidak tahu

Peneliti Apakah menurut Anda model pembelajaran yang digunakan dosen dalam pembelajaran, khususnya mata kuliah metodologi penelitian mampu memberikan pengaruh untuk meningkatkan keterampilan berpikir kritis Anda?

M18 Mungkin sangat berpengaruh $\mathrm{Bu}$.

M7 $\quad \mathrm{YaBu}$.

Peneliti Coba jelaskan faktor-faktor apa saja menurut Anda yang menyebabkan Anda dapat meningkatkan keterampilan berpikir kritis?

M18 Pertama, karena kami memerlukan buku pegangan untuk memahami materi $B u$. Kedua, pada saat penulisan proposal kami memerlukan panduan Bu karena kami tidak memahami langkah-langkah atau indikator-indikator berpikir kritis. Ketiga, pada saat proses pembelajaran kami perlu melakukan latihan-latihan untuk menemukan hal yang selama ini belum pernah kami alami. Salah satunya kami mungkin perlu melihat berbagai contoh cara pemilihan desain penelitian atau pemilihan sampel penelitian . Dengan demikian kami jadi memahami materi desain penelitian dan sampel penelitian. Mungkin dengan demikian kami jadi terbiasa berpikir dengan kritis.
\end{abstract}

Perlu latihan yang berulang $\mathrm{Bu}$, karena dengan latihan berulang kali M7 mungkin kami dapat memperbaiki keterampilan berpikir kritis kami. Selain itu kami memerlukan buku panduan Bu.

Facione (2015) berpendapat bahwa berpikir kritis pada dasarnya merupakan deskripsi yang rinci dari beberapa karakteristik yang meliputi proses interpretasi, analisis, evaluasi, inferensi, eksplanasi, dan regulasi diri [20]. Terdapat beberapa hal yang menjadi ciri umum dari berpikir kritis, di antaranya mampu membuat dan mengevaluasi kesimpulan dengan menelaah permasalahan, bukti, dan solusi secara logis dan sistematis [12]. Hasil analisis menunjukkan ratarata keterampilan berpikir kritis mahasiswa masih tergolong sangat rendah yaitu $25,8 \%$. Berdasarkan triangulasi data juga ditemukan jawaban bahwa mahasiswa masih belum memahami yang dimaksud dengan berpikir kritis. Mahasiswa juga masih belum mampu menerapkan pengetahuan dan konsep yang dimilikinya untuk diterapkan dalam proses analisis artikel ilmiah. Mahasiswa mengetahui konsep namun belum tentu dapat menerapkannya [21]. Randahnya keterampilan berpikir kritis juga disebabkan kurangnya latihan dalam berbagai permasalahan ilmiah, terbatasnya sumber belajar, persepsi yang bias, dan waktu pembelajaran yang membatasi perkembangan berpikir mahasiswa [22]. Selain itu mahasiswa terbiasa menghafal, sedikit menguasai konsep, dan tidak terlatih berpikir [23]. Mahasiswa juga kurang memiliki pengetahuan dasar sehingga kesulitan dalam menyelesaikan masalah dan mencari alternatif penyelesaian masalah.

Proses pembelajaran hendaknya memuat keterampilan-keterampilan berpikir kritis yang harus dimiliki mahasiswa. Mahasiswa harus mampu menginterpretasi, menganalisis, mengevaluasi, menginferensi, meneksplanasi dan bahkan harus mampu memiliki pemikiran regulasi diri dengan mampu menemukan solusi alternatif dalam suatu permasalahan dan juga 
pengambilan keputusan. Hal ini sejalan dengan pendapat Snyder \& Snyder (2008) yang menyatakan bahwa latihan yang kurang dalam melakukan evaluasi dapat mengakibatkan keterampilan berpikir kritis peserta didik rendah [23].

Keterampilan berpikir sangat dipengaruhi oleh pengalaman belajar yang diperoleh oleh mahasiswa.. Adanya aktivitas belajar yang melatih keterampilan berpikir kritis akan sangat berpengaruh terhadap perkembangan keterampilan berpikir kritis mahasiswa. Dosen sebagai pendidik harus menemukan suatu pendekatan, model, ataupun metode yang tepat agar mahasiswa dapat berlatih meningkatkan keterampilan berpikir kritisnya dengan baik. Diperlukan media dan sumber belajar yang memfasilitasi ketercapaian yang diharapkan dengan mengatasi solusi keterbatasan waktu dan luasnya pengetahuan yang harus dimiliki mahasiswa. Emerson (2013) menyatakan bahwa pendidik harus menemukan metode pembelajaran yang dapat melibatkan peserta didik dalam melatih keterampilan berpikir kritis peserta didik [8].

\section{Kesimpulan}

Hasil penelitian menunjukkan bahwa keterampilan berpikir kritis mahasiswa Program Studi Pendidikan Fisika Universitas Palangka Raya berada pada kategori sangat rendah. Mahasiswa yang mencapai indikator keterampilan berpikir kritis masih di bawah 55\%. Hasil penelitian ini memberikan gambaran bagi dosen, tenaga pendidik, dan para peneliti mengenai kondisi keterampilan berpikir kritis mahasiswa Program Studi Pendidikan Fisika Universitas Palangka Raya.. Hasil penelitian ini dapat digunakan sebagai acuan untuk merancang dan mengembangkan proses pembelajaran yang dapat meningkatkan keterampilan berpikir kritis mahasiswa.

\section{Referensi}

[1] Rienties, B., Brouwer, N., \& Lygo-Baker, S. (2013). The effects of online professional development on higher education teachers' beliefs and intentions towards learning facilitation and technology. Teaching and Teacher Education, 29, 122-131.

[2] Avalos, B. (2011). Teacher professional development in teaching and teacher education over ten years. Teaching and Teacher Education, 27, 10-20.

[3] Usman, U. M. (2011). Menjadi guru profesional. Bandung: Remaja Rosdakarya.

[4] Jalal, F. (2007). Sertifikasi guru untuk mewujudkan pendidikan yang bermutu. Surabaya: Seminar Nasional Pascasarjana Unair.

[5] Liliasari. (2005). Membangun keterampilan berpikir manusia Indonesia melalui pendidikan sains. Bandung: Pidato Pengukuhan Guru Besar Universitas Pendidikan Indonesia dalam Pendidikan IPA.

[6] Sudarmin. (2007). Pengembangan model pembelajaran kimia (MPK) terintegrasi kemampuan generik sains sebagai upaya meningkatkan keterampilan berpikir tingkat tinggi calon guru kimia. Semarang: Laporan Hibah Bersaing Universitas Negeri Semarang.

[7] Brotosiswojo, B. S. (2001). Hakekat pembelajaran MIPA dan kiat pembelajaran kimia di perguruan tinggi. Jakarta: PAU-PPAI.

[8] Emerson, M. K. (2013). A model for teaching critical thinking.. Diakses dari http://files.eric.ed.gov/fulltext/ED540588.pdf.

[9] Costa, A. L., \& Pressceincen, B. Z. (1985). Developing minds: A resource book for teaching thinking. Alexandria: ASCD

[10] Ennis, R. H. (1996). Critical thinking. New York: Prentice Hall.

[11] Novak, \& Gowin. (1985). Learning how to learn. Cambridge: Cambridge University Press.

[12] Woolfolk, A. (2009). Educational psychology. New York: Pearson.

[13] Douglas, F., \& Nancy, F. (2007). Checking for understanding: Formative assessment techniques for your classroom. Alexandria: ASCD 
[14] Sarwi, Rusilowati, \& Khanafiyah. (2012). Implementasi model eksperimen gelombang open-inquiry untuk mengembangkan keterampilan berpikir kritis mahasiswa fisika. Jurnal Pendidikan Fisika Indonesia, 8, 41-50

[15] Fisher, A. (2009). Berpikir kritis: Sebuah pengantar. Jakarta: Erlangga.

[16] Eggen, P., \& Kauchak, D. (2012). Strategi dan model pembelajaran. Boston: Pearson Education Inc.

[17] Prahmana, R. C., Kusumah, Y. S., \& Darhim. (2016). Keterampilan mahasiswa dalam melakukan penelitian pendidikan Matematika melalui pembelajaran berbasis riset. Beta, 9 (1), 1-14.

[18] Prahmana, R. C. (2015). Hubungan antara keterampilan meneliti dan pembuatan skripsi mahasiswa pendidikan Matematika. Jurnal Numeracy, II (2), 115-122.

[19] Arikunto, S. (2013). Prosedur penelitian: Suatu pendekatan praktek. Jakarta: Rineka Cipta.

[20] Facione, P. A. (2015). Critical thinking: What it is and why it counts. Dipetik November 24, 2016, dari https://www.insightassessment.com/content/.../ what\&why.pdf.

[21] Carson, J. (2007). A problem with problem solving: teaching thinking without teaching knowledge. The Mathematics Educator. 17, (2), 7-14.

[22] Peter, E. E. (2012).. Critical thinking: essence for teaching mathematics and mathematics problem solving skill.. African Journal of Mathematics and Computer Science research, $5,(3), 39-43$.

[23] Snyder, L. G. \& Snyder, M. J. (2008). Teaching critical thinking and problem solving skill. Delta Pi Epsilon Journal. 50, (2), 90-99, Spring-Summer 2008. 